\title{
ДИНАМІКА ПРОФЕСІЙНОГО СТАНОВЛЕННЯ СТУДЕНТІВ
}

\author{
УДК: 159.9 .075
}

\section{Столярчук Олеся Анатолӥ̈на}

Кандидат психологічних наук, дочент, дочент кафедри загальної, вікової та педагогічної психології Київського університету імені Бориса Грінченка, м. Київ (Украӥна)

\begin{abstract}
Анотація. У роботі розкрито результати дослідження динаміки професійного становлення студентів. Внаслідок теоретичного аналізу наукових джерел структурними компонентами професійного становлення особистості на етапі ї̈ фахового навчання виокремлено цілі, ресурси та Я-конщепцію. Зафіксовано найбільші середньостатистичні показниками изільового компоненту професійного становлення майбутніх психологів, юристів $i$ педагогів. Встановлено, що найменшими є середні показники ресурсного компоненту. Виявлено несприятливу динаміку професійного становлення студентів під час здобуття ними першого бакалаврського рівня. Водночас зафіксовано зростаючі показники професійного становлення респондентів під час їх навчання в магістратурі. Встановлено несприятливу динаміку цільового компоненту професійного становлення студентів з одночасною тенденцією зростання показників ресурсів. Зафіксовано, щчо Я-конщепція має проблемний суперечливий характер формування впродовж фахового навчання майбутніх юристів і педагогів.
\end{abstract}

Ключові слова: професійне становлення, фахове навчання, компоненти професійного становлення студентів, иільовий компонент, ресурсний компонент, компонент Якониепиіiі.

Постановка проблеми. Складності ність вдосконалення педагогічної взаємодії розвитку вітчизняної економіки та соціальної сфери розповсюджуються й на працевлаштування фахівців-початків. Сучасний випускник вищого навчального закладу повинен мати розвинену професійну мобільність, гнучкість, адаптивність як базові особистісні характеристики його конкурентоспроможності. Особистісно зорієнтований підхід вищої школи до якісної підготовки фахівців зумовлює необхідвикладачів і студентів. Доречним є оновлення теоретико-методологічного підгрунтя професіоналізації особистості на етапі фахової підготовки, яке, в свою чергу, уможливлює покращення психолого-педагогічного супроводу професійного становлення студента.

Аналіз останніх досліджень і публікацій. Професійне становлення особистості стало предметом ретельного наукового вивчення 
плеяди зарубіжних

(Г. С. Абрамова,

В. А. Бодров,

А. О. Деркач,

Е. Ф. Зеєр,

А. К. Маркова,

А. Маслоу,

Л. М. Мітіна,

Ю. П. Поваренков, А. О. Реан, К. Роджерс, Д. С'юпер, О. Р. Фонарьов тощо) і вітчизняних вчених

(О. Ф. Бондаренко,

М. Й. Боришевський,

Л. Ф. Бурлачук,

Н. Ю. Волянюк, Н. П. Зубалій, О.М.Кокун,

С. Д. Максименко, В. Ф. Моргун, В. Г. Панок,

Н. А. Побірченко,

Н. І. Пов’якель,

Л. Г. Подоляк, М. В. Савчин, В. А. Семиченко,

О. П. Сергєєнкова,

О. Г. Солодухова,

В. А. Татенко,

Т. М. Титаренко,

Н. В. Чепелєва, Ю. М. Швалб, В. М. Шмаргун,

В. І. Юрченко, Т. С. Яценко та ін.).

Поняття становлення $є$ базовою міждисциплінарною категорією, що підлягає альтернативному тлумаченню. Слушною є думка російських психологів В. І. Слободчикова й Є. I. Ісаєва, які розглядають процес становлення як складову процесу розвитку. На думку вищеозначених дослідників, категорія розвитку одночасно містить у собі як мінімум три процеси: становлення, формування, перетворення. Становлення - це перехід від одного певного стану до іншого - більш високого рівня; єдність вже здійсненого і потенційно можливого [8, с. 26]. Позиція цих авторів доречно відображає активний характер становлення особистості. Нам особливо імпонує тлумачення співзасновника гуманістичної психології А. Маслоу того, що становлення - процес розвитку, в якому індивід бере на себе відповіда- льність за максимально повну реалізацію свого потенціалу [11, с. 525].

Професійне становлення вважаємо продовженням загального особистісного становлення, але в межах нової специфічної взаємодії індивіда 3 соціальним середовищем, що визначається умовами та змістом майбутньої професійної діяльності. Під професійним становленням фахівця розуміється процес прогресивної зміни його особистості внаслідок соціальних впливів, професійної діяльності та власної активності, спрямованої на самоудосконалення i самоздійснення. Становлення обов'язково передбачає потребу у розвитку i саморозвитку, можливість і реальність іiі задоволення, а також потребу у професійному самозбереженні [3, с. 29].

Щодо питання диференціації понять «професійне становлення» та «професійний розвиток» у науці склалися три тенденції. Зокрема розповсюдженим є ототожнення цих понять або розуміння професійного розвитку як аспекту фахового становлення особистості. Приміром, вітчизняний дослідник Н. Ю. Волянюк тлумачить процес професійного становлення як психологічну категорію, що відображає процес саморозвитку людини впродовж життя, у межах якого відбувається становлення специфічних видів суб'єктної активності особистості на основі розвитку і структурування сукупності професійно орієнтованих іiі характеристик, що забезпечують реалізацію функцій пізнання, спілкування та регуляції в 
конкретних видах діяльності і на етапах професійного шляху. Враховуючи сутність поняття генезису як динаміки зародження і розвитку основних мотиваційно-потребових, когнітивних, емоційно-вольових, характерологічних та інших компонентів особистості та формування як результат активних форм впливу зовнішніх і внутрішніх чинників на процес розвитку, вищезазначений автор розглядає поняття становлення переважно як результат генезису і формування [2, с. 25].

Також український науковець О. М. Кокун зазначає, що у більшості авторів поняття «професійний розвиток» вживається в якості синонімічного до поняття «професійне становлення». На його ж думку, поняття професійного становлення $є$ ширшим за професійний розвиток, який можна вважати за основний, але не єдиний компонент професійного становлення фахівця [4, с. 9].

Водночас частина дослідників, позицію яких ми розділяємо, схильні розмежовувати поняття професійного розвитку особистості та професійного становлення як його етапу, що локалізується у межах професійного вибору та фахового навчання. Нам особливо імпонує думка С. Д. Максименка про те, що сутність професійного становлення полягає в тому, що індивід, прийнявши на себе професійну роль, лише розпочинає освоєння функціонального змісту професійної діяльності [5, с.14].

Розглядаючи зміст професійного становлення особистості, ряд науковців тлумачить його $з$ позицій багатоаспектної взаємодії компонентів. Зокрема, дослідниця S. Nyström наголошує, що процес становлення професіонала продовжується впродовж всього трудового життя. Цей процес зображується як сполучна ланка між робочим місцем, виконуваними робочими завданнями і цінностями та цілями індивіда. Але становлення професіонала також залежить від гендерних процесів і практики на робочому місці $[13$, с. 8$]$.

Е. Ф. Зеєр розглядає професійне становлення як формування професійної спрямованості, компетентності, соціально значущих i професійно важливих якостей і їх інтеграція, готовність до постійного професійного зростання, пошук оптимальних прийомів якісного та творчого виконання діяльності у відповідності до індивідуально-психологічних особливостей людини [3, с. 30].

Підкреслюючи багатогранність професійного становлення, В.Ф. Орлов тлумачить його як:

- процес перетворення сформованих професійних якостей;

- етап розвитку професійної культури, на якому професійні якості вже сформувалися, але професійна діяльність не набула остаточної форми;

- форму відображення у свідомості індивіда власного об'єктивно-реального розвитку особистісних професійних якостей;

- рух до розв'язання суперечності між наявними рефлексивними уявленнями, спосо- 
бами мислення, знаннями, уміннями та навичками професійної діяльності і відсутністю досвіду їх реалізації на практиці, між минулим досвідом особистісного розвитку та майбутнім розвитком професійної майстерності, культури праці, між двома етапами усвідомлення власного Я: Я-студент, що опановує професію, і Я-фахівець [6, с. 58].

Російська дослідниця Л. Б. Шнейдер визначає професійне становлення особистості як формування професійної спрямованості, компетентності, соціально значущих і професійно важливих якостей і їх інтеграції, готовність до постійного особистісного і професійного зростання [12, с. 23]. Перегукуються 3 цією тезою погляди В. О. Бодрова, який вважає, що професійне становлення майбутнього фахівця залежить від певних характеристик людини, які визначально детермінують кінцевий успіх формування студента як професіонала, його професійну готовність та у сукупності зумовлюють іiі рівень. Основними такими характеристиками, на думку вченого, $є$ :

- професійна мотивація як спонукальна та спрямовуюча активність особистості на задоволення не тільки біологічних потреб, але насамперед потреб у праці, спілкуванні, самоствердженні, самореалізації, самовдосконаленні;

- загальна і професійна підготовленість у формі попередніх (для опанування професіi) і кваліфікаційних (з урахуванням рівня професіоналізації) знань, навичок і вмінь, необхідних для виконання стандартних та нетипових професійних завдань;

- рівень функціональної готовності та резервів організму до трудової діяльності, розвиток професійно важливих фізіологічних функцій аналізаторів і фізичних якостей (сила, швидкість, витривалість);

- стан індивідуально-психологічних функцій людини і насамперед професійно важливих якостей для конкретної діяльності, що характеризують пізнавальні процеси та психомоторику, темперамент, характерологічні й емоційно-вольові особливості особистості [1, с. 128].

Також ряд дослідників вказують на структурні компоненти парціальних аспектів професійного становлення особистості. Зокрема, вітчизняний вчений I. Л. Уличний у структурі професійного самовизначення як початкового етапу професійного становлення особистості виокремлює мотиваційний, когнітивний, поведінковий компоненти та Яконцепцію [10, с. 192]. По завершенні фахового навчання у потенційного суб'єкта праці формується професійна готовність, змістом якої, за думкою Л. В. Пляки, є інтегральні характеристики особистості майбутніх фахівців, що включають у себе такі компоненти: мотиваційний, когнітивний, особистісний та вольовий [7, с.12].

Таким чином, альтернативні тлумачення змісту професійного становлення особис- 
тості провокують проблему застосування чітких маркерів практичного дослідження цього феномену. Для вирішення цієї проблеми виокремлено структурні компоненти професійного становлення особистості та розроблено й апробовано методику їх діагностики на етапі фахового навчання.

Метою статті $\epsilon$ аналіз результатів дослідження динаміки компонентів професійного становлення особистості на етапі ऑï фахового навчання.

Виклад основного матеріалу та результатів дослідження. Аналіз та інтеграція наукових підходів 3 питань тлумачення психологічних проявів професійного становлення особистості на етапі іï фахового навчання дає підгрунтя для розкриття суті цього процесу через три взаємопов'язані компоненти (рис. 1).

Застосування авторської методики діагностики рівня та типу професійного становлення студентів [9] дозволило виявити динаміку структурних компонентів та загального рівня фахового становлення майбутніх фахівців. Вибірку склали студенти 1-6 курсів трьох спеціальностей, зокрема майбутні психологи, юристи та учителі, загальною кількістю 589 осіб. У ході констатувального експерименту застосовано методи анкетування, визначення середніх значень і порівняльного аналізу.

Запорукою успішного опанування професії під час фахового навчання та подальшої професійної самореалізації є розвинений ці- льовий компонент. У майбутніх психологів простежується стійка тенденція несприятливої динаміки цього компоненту через щорічне зниження показників 3 першого по четвертий роки навчання. Лише третій курс характеризується несуттєвим зростанням рівня ці-

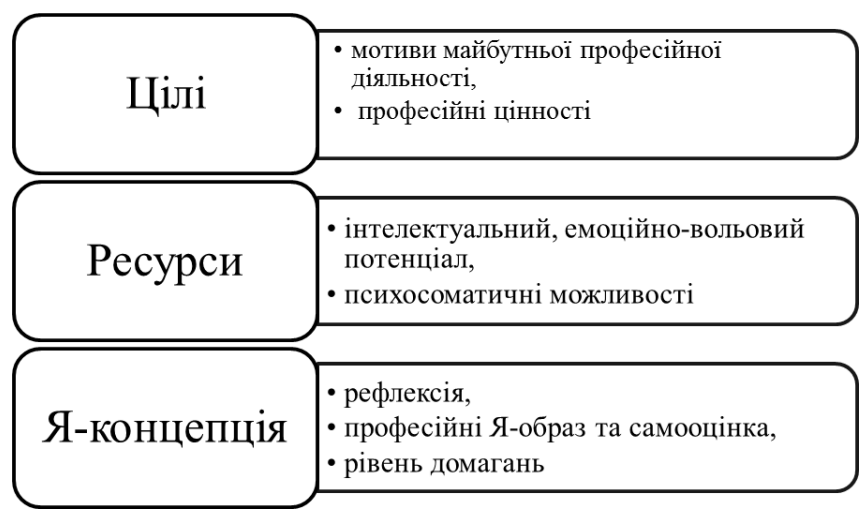

Рис 1. Особливості прояву типів монетарних уявлень студентів України та Свропейського Союзу.

льового компоненту. У виграшному становищі знаходяться студенти магістратури, які демонструють значне зростання показників цільового компоненту професійного становлення (табл. 1).

Несприятливу тенденцію суттєвого зниження показників цільового компоненту професійного становлення виявлено упродовж фахового навчання майбутніх юристів. Сумніви у правильності обраної професії з'являються у цих студентів ще на другому курci, а третьокурсники гостро переживають кризу професійної апробації, під час якої показники цільового компоненту стають найнижчими. Не надто покращує ситуацію завер- 
Динаміка цільового компоненту професійного становлення студентів

\begin{tabular}{|l|c|c|c|c|c|c|}
\hline \multirow{2}{*}{$\begin{array}{l}\text { Показники } \\
\text { Салах) }\end{array}$} & & & & & & \\
\cline { 2 - 7 } & 1 курс & 2 курс & 3 курс & 4 курс & 5 курс & 6 курс \\
\hline Психологія & & & & & & \\
\hline Правознавство & 24,30 & 22,40 & 22,97 & 21,03 & 23,20 & 25,08 \\
\hline Педагогіка & 24,58 & 22,54 & 19,35 & 20,85 & 20,4 & 21,71 \\
\hline
\end{tabular}

шення бакалаврського навчання та вступ до магістратури, лише у студентів шостого курсу показники сформованості цільового компоненту дещо зростають.

Початок фахового навчання засвідчив сприятливу динаміку цільового компоненту професійного становлення майбутніх учителів. Однак третій і четвертий курси їх навчання, супроводжуючись переживанням криз апробації та фахової готовності, дають зниження показників цільового компоненту. Натомість магістранти продемонстрували тенденцію його зростання.

Ресурсний компонент постає підгрунтям успішного професійного становлення сту- дентів. Виявлення його середнього рівня засвідчило сприятливу тенденцію збагачення психосоматичного потенціалу опитаних трьох спеціальностей упродовж їх фахового навчання (табл. 2).

Деяке зниження показників ресурсів простежується у студентів, які здобувають професії психолога й юриста, на другому та п’ятому курсах, однак завершення навчання у магістратурі супроводжується зростанням цього компоненту. Для майбутніх учителів маркером зменшення ресурсного потенціалу $є$ лише третій курс, а згодом показники цього компоненту стабільно зростають, особливо впродовж навчання у магістратурі.

Таблиия 2

Динаміка ресурсного компоненту професійного становлення студентів

\begin{tabular}{|c|c|c|c|c|c|c|}
\hline \multirow{2}{*}{$\begin{array}{r}\text { Показники } \\
\text { (у балах) }\end{array}$} & & & & & & \\
\hline & 1 курс & 2 курс & 3 курс & 4 курс & 5 курс & 6 курс \\
\hline Психологія & 21,14 & 20,23 & 22,19 & 22,00 & 21,20 & 23,46 \\
\hline Правознавство & 21,95 & 21,92 & 20,28 & 22,65 & 21 & 23,71 \\
\hline Педагогіка & 20,04 & 22,82 & 20,10 & 20,53 & 22,62 & 24,39 \\
\hline
\end{tabular}


Квінтесенцією особистісних змін під час професійного становлення студентів $€$ їх професійна Я-концепція. У майбутніх психологів виявлено сприятливу динаміку зростання показників сформованості цього компоненту впродовж фахового навчання (табл. 3). Проблемним $є$ лише другій рік навчання студентів-психологів, де має місце деяке зниження показників сформованості Я-концепції, а наступні курси, включаючи й здобуття другого магістерського рівня, характеризуються рактеризується деяким зростанням рівня сформованості Я-концепції майбутніх юристів.

Адаптація до початку фахового навчання студентів, що здобувають педагогічну професію, характеризується зростанням показників їх Я-концепції. Однак, третій і четвертий роки навчання супроводжуються значним зменшенням цих показників. Сприятлива динаміка формування професійної Я-концепції майбутніх учителів простежується під час їх навчання у магістратурі, де показники стають

Таблиия 3

Динаміка Я-концепції як компоненту професійного становлення студентів

\begin{tabular}{|l|l|l|l|l|l|l|}
\hline \multirow{2}{*}{$\begin{array}{r}\text { Показники } \\
\text { Спеціальність }\end{array}$} & & & & & & \\
\cline { 4 - 8 } & & & & & & \\
\hline Психологія & 22,02 & 20,30 & 20,83 & 22,17 & 23,33 & 24,54 \\
\hline Правознавство & 24,89 & 22,96 & 20,70 & 23,75 & 20,6 & 22,48 \\
\hline Педагогіка & 21,39 & 23,57 & 20,63 & 19,93 & 22,31 & 24,39 \\
\hline
\end{tabular}

стабільним підвищенням її рівня.

Натомість у майбутніх юристів бакалаврське навчання супроводжується зниженням рівня сформованості Я-концепції на другому та третьому курсах і зростає вже на випускному четвертому, однак не досягаючи показників першого курсу. Початок навчання у магістратурі виглядає справжнім випробуванням для студентів, що здобувають юридичний фах, оскільки тут показники сформованості їх Я-концепції є найнижчими. Шостий курс ха- найвищими.

Загальний рівень професійного становлення найвищим $є$ у першокурсників, що здобувають юридичну спеціальність. На другому та третьому курсах його показники суттєво знижуються, і хоча на випускних четвертому та шостому курсах загальний рівень професійного становлення майбутніх юристів зростає, але все одно не досягає показників початку фахового навчання, що свідчить про несприятливу динаміку (табл. 4). Натомість показники загального рівня професійного становлен- 
ня майбутніх психологів і педагогів суттєво зростають порівняно з першим курсом. Однак це стосується завершення магістратури, оскільки у випускників четвертого курсу ці показники значно нижчі, ніж у першокурсників.

У майбутніх психологів простежується нестабільна динаміка рівня професійного становлення упродовж здобуття освітнього рівня ми середньостатистичними показниками серед компонентів професійного становлення майбутніх психологів, юристів і педагогів $є$ показники цільового компоненту, а найменшими - ресурсного. Виявлено несприятливу динаміку професійного становлення майбутніх юристів, а саме його загального рівня, цільового компоненту та компоненту Я-

Таблиия 4

\section{Динаміка загального рівня професійного становлення студентів}

\begin{tabular}{|l|c|c|c|c|c|c|}
\hline & $\begin{array}{r}\text { Показники } \\
\text { (у балах) }\end{array}$ & & & & & \\
Спеціальність & 1 курс & 2 курс & 3 курс & 4 курс & 5 курс & 6 курс \\
\hline Психологія & & & & & & \\
\hline Правознавство & 67,42 & 63,05 & 66,25 & 64,97 & 67,20 & 73,08 \\
\hline Педагогіка & 71,37 & 67,04 & 60,33 & 67,1 & 66,25 & 67,9 \\
\hline
\end{tabular}

бакалавра - зниження показників на другому та четвертому курсах, яке чергується зі зростанням на інших курсах. У майбутніх учителів, навпаки, другій рік навчання супроводжується суттєвим підвищенням загального рівня професійного становлення, а наступні третій та четвертий курс характеризуються зниженням показників, що вказує на загалом несприятливу динаміку. Спільною для трьох спеціальностей $є$ позитивна тенденція зростання рівня професійного становлення під час навчання у магістратурі.

Висновки. Отже, структурними компонентами професійного становлення особистості на етапі іiі фахового навчання виокремлено цілі, ресурси й Я-концепцію. Найбільши- концепції, що свідчить про кризовий характер фахової ідентифікації цих студентів. Зменшення показників рівня професійного становлення під час здобуття першого бакалаврського рівня характерне й для майбутніх психологів і педагогів. Водночас зафіксовано сприятливу динаміку професійного становлення цих студентів під час їх навчання в магістратурі. Встановлено несприятливу динаміку цільового компоненту професійного становлення студентів з одночасною тенденцією зростання показників ресурсів. З'ясовано, що Яконцепція має проблемний суперечливий характер формування впродовж фахового навчання майбутніх юристів і педагогів. 
Перспективи подалыших наукових розвідок вбачаємо у виявленні найбільш впливових психологічних чинників професійного становлення студентів і розробці й апробації заходів його оптимізації.

\section{Перелік використаних джерел:}

1. Бодров В. А. Психология профессиональной пригодности: учебное пособие для вузов / В. А. Бодров. - М.: ПЕР СЭ, 2001. - $511 \mathrm{c}$.

2. Волянюк Н. Ю. Профессиональное развитие субъекта деятельности / Н. Ю. Волянюк // Физическое воспитание студентов творческих специальностей: сб. науч. тр. / под ред. С. С. Ермакова. - Харьков: ХГАДИ (ХХПИ), 2003. - С. 37-47.

3. Зеер Э. Ф. Психология профессий: учебн. пособ. / Е.Ф. Зеер. - 3-е изд., перераб. И доп. - М.: Академический Проект, Фонд «Мир», 2005. - 336 с.

4. Кокун О. М. Психологія професійного становлення сучасного фахівця: Монографія / О. М. Кокун. - К.: ДП «Інформ.-аналіт. агенство», 2012. - 200 с.

5. Максименко С. Д. Професійне становлення молодого вчителя / С. Д. Максименко, Т. Д. Щербан. - Ужгород: Закарпаття, 1998. - 106 с.

6. Орлов В.Ф. Професійне становлення вчителів мистецьких дисциплін: монографія / В. Ф. Орлов. - К.: Наукова думка, 2003. - 262 с.

7. Пляка Л. В. Структура професійної готовності майбутніх фахівців фармацевтичної галузі / Л. В. Пляка // Придніпровські соціально-гуманітарні читання: матеріали III Всеукр. наук.-практ. конф. (Дніпропетровськ, 29 листопада 2014 р.): у 4-х частинах. - Д.: ТОВ «Інновація», 2014. - Ч. 2. - С. 11-12.

8. Слободчиков В. И. Основы психологической антропологии. Психология развития человека: Развитие субъективной реальности в онтогенезе: учебное пособие для вузов / В. И. Слободчиков, Е. И. Исаев. - М.:
Школьная пресса, 2000. - 421 с.

9. Столярчук O. А. Опис та психометричні характеристики психодіагностичної методики «Рівень і тип професійного становлення студентів» / О. А. Столярчук // Вища освіта України у контексті інтеграції до європейського освітнього простору: тематичний випуск Гуманітарного вісника ДВНЗ «Переяслав-Хмельницький державний педагогічний університет імені Григорія Сковороди»: зб. наук. пр. - Дод. 1. до вип. 37. T. IV (72). - К.: Гнозис, 2016. - С. 237-251.

10. Уличний I. Л. Психологічні складові структури професійного самовизначення старшокласників / І. Л. Уличний // Актуальні проблеми психології: зб. наук пр. - 2010. - Т. 7. - Вип. 22. - С.191-196.

11. Хьелл Л. Теории личности (основные положения, исследования, применение) / Л. Хьелл, Д. Зиглер. СПб.: Питер Ком, 1999. - 608 с.

12. Шнейдер Л. Б. Профессиональная идентичность: теория, эксперимент, тренинг: учеб. пособие / Л. Б. Шнейдер. - М.: Издательство Московского психологосоциального института; Воронеж: Издательство НПО «МОДЭК», 2004. - 600 c.

13. Sofia Nyström. Becoming a professional. A longitudinal study of graduates' professional trajectories from higher education to working life. http://liu.diva-portal.org/smash/ get/diva2:174874/FULLTEXT02.pdf

\section{References (Transliteration):}

1. Bodrov $V$. A. Psikhologiya professionalnoy prigodnosti: uchebnoe posobie dlya vuzov / V. A. Bodrov. - M.: PYeR SE, 2001. - $511 \mathrm{~s}$.

2. Volyanyuk N. Yu. Professionalnoe razvitie subekta deyatelnosti / N. Yu. Volyanyuk // Fizicheskoe vospitanie studentov tvorcheskikh spetsialnostey: sb. nauch. tr. / pod red. S. S. Yermakova. - Kharkov: KhGADI (KhKhPI), 2003. - S. 37-47.

3. Zeer E. F. Psikhologiya professiy: uchebn. posob. / Ye.F. Zeer. - 3-e izd., pererab. I dop. - M.: Akademicheskiy 
Proekt, Fond «Mir», 2005. - 336 s.

4. Kokun O. M. Psykholohiya profesiynoho stanovlennya suchasnoho fakhivtsya: Monohrafiya / O. M. Kokun. - K.: DP «Inform.-analit. ahenstvo», 2012. - $200 \mathrm{~s}$.

5. Maksymenko S. D. Profesiyne stanovlennya molodoho vchytelya / S. D. Maksymenko, T. D. Shcherban. Uzhhorod: Zakarpattya, 1998. - 106 s.

6. Orlov V. F. Profesiyne stanovlennya vchyteliv mystets'kykh dystsyplin: monohrafiya / V. F. Orlov. - K.: Naukova dumka, 2003. - 262 s.

7. Plyaka L. V. Struktura profesiynoyi hotovnosti maybutnikh fakhivtsiv farmatsevtychnoyi haluzi / L. V. Plyaka // Prydniprovs'ki sotsial'no-humanitarni chytannya: materialy III Vseukr. nauk.-prakt. konf. (Dnipropetrovs'k, 29 lystopada 2014 r.): u 4-kh chastynakh. - D.: TOV «Innovatsiya», 2014. - Ch. 2. - S. 11-12.

8. Slobodchikov V. I. Osnovy psikhologicheskoy antropologii. Psikhologiya razvitiya cheloveka: Razvitie subektivnoy realnosti v ontogeneze: uchebnoe posobie dlya vuzov / V. I. Slobodchikov, Ye. I. Isaev. - M.: Shkolnaya pressa, 2000. $-421 \mathrm{~s}$.

9. Stolyarchuk O. A. Opys ta psykhometrychni kharakterystyky psykhodiahnostychnoyi metodyky «Riven' i typ profesiynoho stanovlennya studentiv» / O. A. Stolyarchuk // Vyshcha osvita Ukrayiny u konteksti intehratsiyi do yevropeys'koho osvitn'oho prostoru: tematychnyy vypusk Humanitarnoho visnyka DVNZ «Pereyaslav-Khmel'nyts'kyy derzhavnyy pedahohichnyy universytet imeni Hryhoriya Skovorody»: zb. nauk. pr. Dod. 1. do vyp. 37. - T. IV (72). - K.: Hnozys, 2016. - S. 237-251.

10. Ulychnyy I. L. Psykholohichni skladovi struktury profesiynoho samovyznachennya starshoklasnykiv / I. L. Ulychnyy // Aktual'ni problemy psykholohiyi: zb. nauk pr. - 2010. - T. 7. - Vyp. 22. - S.191-196.

11. Khell L. Teorii lichnosti (osnovnye polozheniya, issledovaniya, primenenie) / L. Khell, D. Zigler. - SPb.: Piter Kom, 1999. - $608 \mathrm{~s}$.

12. Shneyder L. B. Professionalnaya identichnost: teoriya, eksperiment, trening: ucheb. posobie / L. B. Shneyder. -
M.: Izdatelstvo Moskovskogo psikhologo-sotsialnogo instituta; Voronezh: Izdatelstvo NPO «MODEK», 2004. $600 \mathrm{~s}$.

13. Sofia Nyström. Becoming a professional. A longitudinal study of graduates' professional trajectories from higher education to working life. http://liu.diva-portal.org/ smash/get/diva2:174874/FULLTEXT02.pdf

\section{Olesia Stoliarchuk}

Ph.D. (Psychological Sciences), Assistant professor of Department of General, Age and Educational Psychology, Borys Grinchenko Kyiv University, Kyiv (Ukraine)

\section{DYNAMIC OF STUDENT'S PROFESSIONAL BECOMING}

\section{ABSTRACT}

The problem of optimization student's professional becoming is disclosed in the article. A professional becoming of personality is stage her professional development. This stage includes choice of profession and professional studying. The scientific approaches of interpretation of the psychological aspects of student's professional becoming were analyzed. The structure of the student's professional becoming has three components. The purpose component has motives of professional activity and professional values of personality. The resource component has cognitive, emotional, volitional potential and psychosomatic opportunities. The component of self-concept has reflection, professional selfimage and self-appraisal.

Results of the research of the dynamic of students' professional becoming are disclosed in the article. It is found out; the purpose component of future psychologists, lawyers and teach- 
ers has the most indicators. The purpose component of future psychologists, lawyers and teachers has the lowest indicators. The unfavorable dynamic of student's professional becoming was founded. Also the unfavorable dynamic of purpose component was founded. The favorable dynamic of resource component was founded at the same time. The contradictory formation has selfconcept of future lawyers and teachers during their professional studying.

Results of the research of the dynamic of student's professional becoming are indicate necessitate of optimization of psychological and pedagogical support of their professional studying.

Key words: professional becoming, professional studying, components of student's professional becoming, purpose component, resource component, component of self-concept.

\section{Столярчук Олеся Анатольевна}

Кандидат психологических наук, доцент, доцеент кафедры общей, возрастной и педагогической психологии, Киевский университет имени Бориса Гринченко, Киев (Украина)

\section{ДИНАМИКА ПРОФЕССИОНАЛЬНОГО СТАНОВЛЕНИЯ СТУДЕНТОВ}

Аннотация. Работа посвящена проблеме оптимизации профессионального становления личности на этапе ее профессионального обучения. Профессиональное становление личности понимается как этап ее профессионального развития, который локализуется в пределах профессионального выбо- ра и профессионального обучения. Анализ и интеграция научных подходов по вопросам толкования психологических проявлений профессионального становления личности на этапе ее профессионального обучения стали основой для раскрытия сути этого процесса через три взаимосвязанных компонента. Целевой компонент профессионального становления студентов содержит мотивы будущей профессиональной деятельности личности и ее профессиональные ценности. Ресурсный компонент реализуется в когнитивном и эмоционально-волевом потенциале, а также психосоматических возможностях. Компонент Яконцепции содержит процесс и результат рефлексии, профессиональные образ «Я» и самооценку и уровень профессиональных притязаний.

В статье раскрыты результаты исследования динамики становления будущих специалистов. Зафиксировано самые высокие среднестатистические показатели целевого компонента профессионального становления будущих психологов, юристов и педагогов. Установлено, что наименьшими являются средние показатели ресурсного компонента. Выявлено неблагоприятную динамику профессионального становления студентов. Установлено неблагоприятную динамику целевого компонента профессионального становления студентов с одновременной тенденцией роста показателей ресурсов. Зафиксировано, что Яконцепция имеет проблемный противоречи- 
вый характер формирования в течение профессионального обучения будущих юристов и педагогов.

Результаты исследования динамики профессионального становления будущих специалистов социономической сферы указывают на необходимость оптимизации психолого-педагогического сопровождения их профессионального обучения.

Ключевые слова: профессиональное становление, профессиональное обучение, компоненты профессионального становления студентов, целевой компонент, ресурсный компонент, компонент Я-концепции. 